\title{
$\mathrm{X}$-linked myotubular myopathy and recurrent spontaneous pneumothorax
}

\section{A new phenotype?}

Per-Ole Carstens, MD, Eva Maria Christina Schwaibold, MD, Katharina Schregel, MD, Carolin D. Obermaier, PHD, Arne Wrede, MD, Sabrina Zechel, MD, Silke Pauli, MD, and Jens Schmidt, MD

Neurol Genet 2019;5:e327. doi:10.1212/NXG.0000000000000327

X-linked myotubular myopathy (XLMTM) is a rare hereditary disorder of the skeletal muscle. Symptoms include impaired respiration and muscular hypotonia, usually present at birth and leading to death during infancy or early childhood. ${ }^{1}$ Pneumothorax, defined as trapping of air in the pleural cavity, can be caused by surgery or can occur spontaneously. ${ }^{2}$ Pneumothorax has been reported only in a small number of cases with hereditary myopathies, but usually not spontaneously and never in XLMTM.

\section{Case report}

Our index patient presented at age 42 because of problems in raising his arms and climbing stairs. His one-year-older brother reported no symptoms. During childhood and adolescence, all motor milestones were reached normally. Both brothers were good at sports, but could not climb up a rope. Chronic bronchitis was diagnosed in both at around age 6, yet no treatment was required. Both started to smoke cigarettes at ages 15 and 16 . Between age 18 and 26, the index patient had recurrent spontaneous pneumothorax (SP), which affected the right lung 9 times and the left lung once. The older brother had a first SP of the left lung at the age of 25 . At the age of 29, 3 instances of SP of the left lung occurred within short intervals and a microsurgical intervention was performed. Several days later, he developed SP of the right lung and received microsurgical intervention of that side. All 5 instances of SP were associated with physical activity. At age 44, the index patient developed respiratory insufficiency and required noninvasive ventilation during the nights and for some hours during the day. An inhalation therapy with tiotropium, formoterol, and budesonide was required, and he stopped smoking. At age 47, another SP of the right lung occurred during non-invasive ventilation (NIV) and a partial lung resection was performed. There was no family history for chronic bronchitis, SP, or neuromuscular disorders.

Chest x-ray revealed no evidence of lung emphysema (figure, A), and alpha-1-antitrypsin deficiency as the cause for SP was genetically excluded (SERPINA1 gene). A moderately combined respiratory disorder was found by body plethysmography.

Clinical examination of the index patient revealed a paresis of arm abduction (muscle research council [MRC] grade 2) and hip flexion (MRC 4). The older brother could not walk on his heels and had no other paresis. Myogenic changes on EMG and slightly elevated creatine kinase (CK) were noted in both patients. The muscle biopsy and MRI of the index patient revealed signs of myopathic damage and displayed fatty degeneration of the muscle (figure, $\mathrm{B}-\mathrm{C}$ ). The

\author{
Correspondence \\ Dr. Schmidt \\ j.schmidt@gmx.org
}



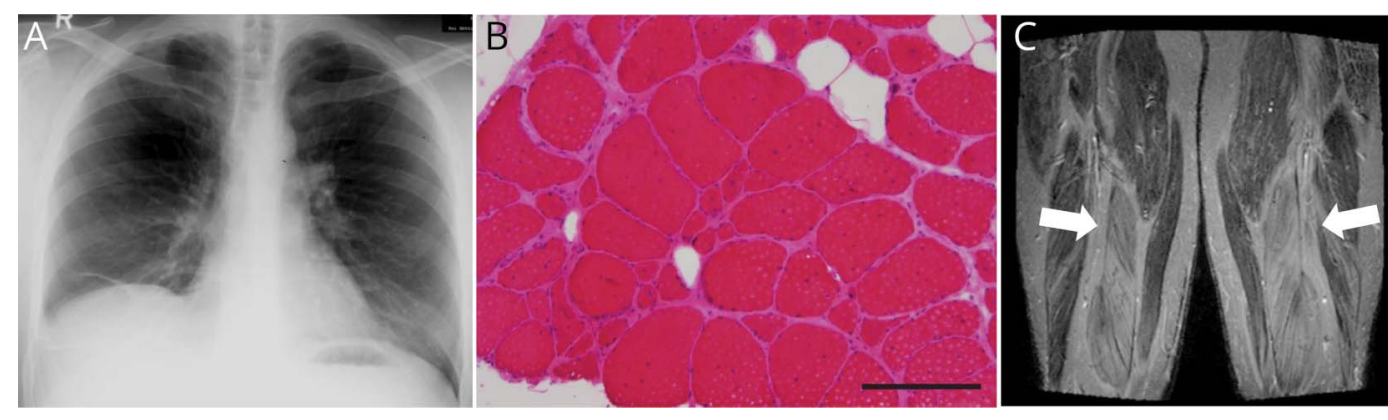

(A) Routine chest $x$-ray of the older brother at the age of 43 displays dystelectasis of the middle lobe of the right side without evidence of lung emphysema. (B) Muscle biopsy of the index patient. Myopathic muscle tissue with internalized nuclei, fiber size variability, and increase of endomysial connective tissue (105 of 220 muscle fibers display an internalized nucleus [47.7\%]). In the older brother, 861 of 1,429 muscle fibers depict an internalized nucleus [60.2\%]). HE staining, scale bar $=200 \mu \mathrm{m}$. (C) Muscle MRI of the index patient. The arrows depict fatty degeneration of the quadriceps muscle. T1w sequence.

diagnosis of XLMTM was based on the detection of the frameshift variant c.98dupA (p.(Ala34Glyfs*13)) in exon 3 of the MTM1 gene in both patients by next-generation sequencing. The patients have no other siblings and their mother died before genetic testing could be performed. Over the following 10 years, both brothers developed proximal and distal tetraparesis, ptosis, and dysphagia, which led to major restrictions in daily life activities.

\section{Discussion}

MTM1 codes for myotubularin, which is involved in mitochondrial homeostasis and regulation of the cytoskeletal system in muscles. ${ }^{3}$ To our knowledge, the here-described variant c.98dupA (p. (Ala34Glyfs $\left.s^{*} 13\right)$ ) has not been described in databases (ExAC, gnomAD, Human Gene Mutation Database) or in the literature before. Truncating variants of $M T M 1$ are normally associated with a more severe phenotype than nontruncating variants. ${ }^{1}$ Although the variant c.98dupA (p.(Ala34Glyfs $\left.{ }^{*} 13\right)$ ) leads to a frameshift with a premature stop codon and a truncated protein or a nonsense-mediated mRNA-decay, interestingly, it was associated with a much more moderate phenotype of adult onset.

In our 2 patients, muscular weakness became apparent after the age of 40 years and respiratory impairment occurred only in one brother after recurrent SP and partial lung resection. Dyspnea on exercise was diagnosed as a chronic bronchitis in childhood but might be interpreted as a mild respiratory failure because of the myopathy.

SP in hereditary myopathy has been reported only in a small number of patients with nemaline myopathy, ${ }^{4}$ limbgirdle muscular dystrophy, ${ }^{5}$ collagen VI-related dystrophy, ${ }^{6}$ and Duchenne muscular dystrophy. ${ }^{7}$ However, most pneumothoraces were nonrecurrent and associated with assisted ventilation. So far, no association between XLMTM and SP has been reported. Because of the recurrent and bilateral appearance of the SP in both brothers, a genetic predisposition can be assumed. The current knowledge of myotubularin is not sufficient to explain why SP may occur.

This case report is of interest for clinicians and human geneticists in 3 different ways: (1) A novel frameshift variant in the MTM1 gene is described. (2) The new variant is associated with a moderate, adult-onset course of XLMTM. (3) The variant might be associated with recurrent SP, which has not been reported before for XLMTM.

\section{Study funding}

No targeted reported funding.

\section{Disclosure}

Disclosures available: Neurology.org/NG.

\section{Publication history}

Received by Neurology: Genetics November 15, 2018. Accepted in final form March 11, 2019.

\section{Appendix Authors}

\begin{tabular}{|c|c|c|c|}
\hline Name & Location & Role & Contribution \\
\hline $\begin{array}{l}\text { Per-Ole } \\
\text { Carstens, } \\
\text { MD }\end{array}$ & $\begin{array}{l}\text { Department of } \\
\text { Neurology, University } \\
\text { Medical Center } \\
\text { Göttingen, Germany }\end{array}$ & Author & $\begin{array}{l}\text { Analyzed the whole } \\
\text { set of clinical data; } \\
\text { drafted the } \\
\text { manuscript for } \\
\text { intellectual content }\end{array}$ \\
\hline $\begin{array}{l}\text { Eva Maria } \\
\text { Christina } \\
\text { Schwaibold, } \\
\text { MD }\end{array}$ & $\begin{array}{l}\text { Institute of Human } \\
\text { Genetics, Heidelberg } \\
\text { University, Germany }\end{array}$ & Author & $\begin{array}{l}\text { Planned and } \\
\text { supervised the } \\
\text { genetic testing; } \\
\text { revised the } \\
\text { manuscript for } \\
\text { intellectual content }\end{array}$ \\
\hline $\begin{array}{l}\text { Katharina } \\
\text { Schregel, } \\
\text { MD }\end{array}$ & $\begin{array}{l}\text { Institute of } \\
\text { Neuroradiology, } \\
\text { University Medical } \\
\text { Center Göttingen, } \\
\text { Germany }\end{array}$ & Author & $\begin{array}{l}\text { Analyzed the muscle } \\
\text { MRI; revised the } \\
\text { manuscript for } \\
\text { intellectual content }\end{array}$ \\
\hline
\end{tabular}




\begin{tabular}{|c|c|c|c|}
\hline Name & Location & Role & Contribution \\
\hline $\begin{array}{l}\text { Carolin D. } \\
\text { Obermaier, } \\
\text { PHD }\end{array}$ & $\begin{array}{l}\text { CeGaT GmbH and } \\
\text { Praxis für } \\
\text { Humangenetik } \\
\text { Tübingen, Germany }\end{array}$ & Author & $\begin{array}{l}\text { Planned and } \\
\text { supervised the genetic } \\
\text { testing; revised the } \\
\text { manuscript for } \\
\text { intellectual content }\end{array}$ \\
\hline $\begin{array}{l}\text { Arne } \\
\text { Wrede, MD }\end{array}$ & $\begin{array}{l}\text { Institute of } \\
\text { Neuropathology, } \\
\text { Saarland University } \\
\text { Medical Center, } \\
\text { Homburg, Germany }\end{array}$ & Author & $\begin{array}{l}\text { Analyzed the muscle } \\
\text { biopsy; revised the } \\
\text { manuscript for } \\
\text { intellectual content }\end{array}$ \\
\hline $\begin{array}{l}\text { Sabrina } \\
\text { Zechel, MD }\end{array}$ & $\begin{array}{l}\text { Institute of } \\
\text { Neuropathology, } \\
\text { University Medical } \\
\text { Center Göttingen, } \\
\text { Germany }\end{array}$ & Author & $\begin{array}{l}\text { Analyzed the muscle } \\
\text { biopsy; revised the } \\
\text { manuscript for } \\
\text { intellectual content }\end{array}$ \\
\hline $\begin{array}{l}\text { Silke Pauli, } \\
\text { MD }\end{array}$ & $\begin{array}{l}\text { Institute of Human } \\
\text { Genetics, University } \\
\text { Medical Center } \\
\text { Göttingen, Germany }\end{array}$ & Author & $\begin{array}{l}\text { Planned and } \\
\text { supervised the genetic } \\
\text { testing; revised the } \\
\text { manuscript for } \\
\text { intellectual content }\end{array}$ \\
\hline $\begin{array}{l}\text { Jens } \\
\text { Schmidt, } \\
\text { MD }\end{array}$ & $\begin{array}{l}\text { Department of } \\
\text { Neurology, University } \\
\text { Medical Center } \\
\text { Göttingen, Germany }\end{array}$ & Author & $\begin{array}{l}\text { Conceptualized and } \\
\text { supervised the } \\
\text { manuscript; revised } \\
\text { the manuscript for } \\
\text { intellectual content }\end{array}$ \\
\hline
\end{tabular}

\section{References}

1. McEntagart M, Parsons G, Buj-Bello A, et al. Genotype-phenotype correlations in X-linked myotubular myopathy. Neuromuscul Disord 2002;12:939-946.

2. Tschopp JM, Rami-Porta R, Noppen M, Astoul P. Management of spontaneous pneumothorax: state of the art. Eur Respir J 2006;28:637-650.

3. Hnia $\mathrm{K}$, Tronchère $\mathrm{H}$, Tomczak KK, et al. Myotubularin controls desmin intermediate filament architecture and mitochondrial dynamics in human and mouse skeletal muscle. J Clin Invest 2011;121:70-85

4. Sasaki M, Yoneyama H, Nonaka I. Respiratory muscle involvement in nemaline myopathy. Pediatr Neurol 1990;6:425-427.

5. Fayssoil A, Ogna A, Chaffaut C, et al. Natural history of cardiac and respiratory involvement, prognosis and predictive factors for long-term survival in adult patients with limb girdle muscular dystrophies type 2C and 2D. PLoS One2016; 11:e0153095.

6. Fraser KL, Wong S, Foley AR, et al. Pneumothoraces in collagen VI-related dystrophy: a case series and recommendations for management. ERJ Open Res 2017;3.

7. Yamamoto T, Kawai M. Spontaneous pneumothorax in Duchenne muscular dystrophy [in Japanese]. Rinsho Shinkeigaku 1994;34:552-556. 


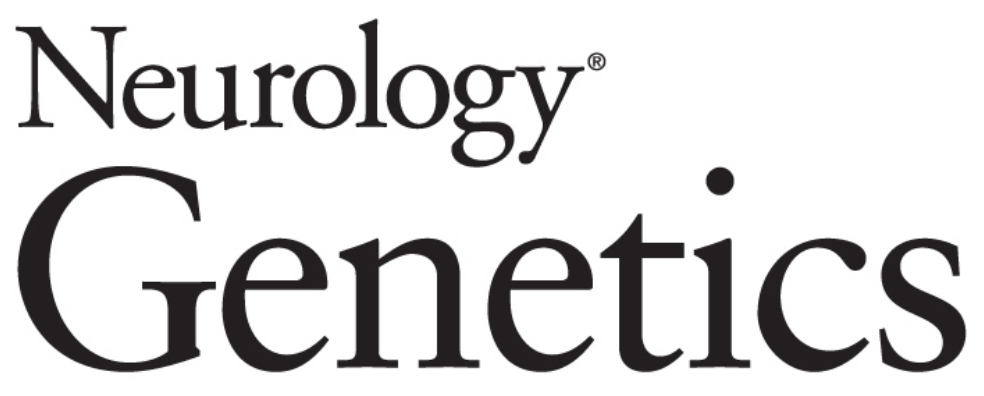

\section{X-linked myotubular myopathy and recurrent spontaneous pneumothorax: A new phenotype? \\ Per-Ole Carstens, Eva Maria Christina Schwaibold, Katharina Schregel, et al. Neurol Genet 2019;5; \\ DOI 10.1212/NXG.0000000000000327}

\section{This information is current as of April 26, 2019}

Updated Information \&
Services
References
Citations
Subspecialty Collections
Permissions \& Licensing
Reprints

\section{Updated Information \&}

References

\section{Citations}

\section{Subspecialty Collections}

Reprints including high resolution figures, can be found at: http://ng.neurology.org/content/5/3/e327.full.html

This article cites 6 articles, 1 of which you can access for free at: http://ng.neurology.org/content/5/3/e327.full.html\#\#ref-list-1

This article has been cited by 2 HighWire-hosted articles: http://ng.neurology.org/content/5/3/e327.full.html\#\#otherarticles

This article, along with others on similar topics, appears in the following collection(s):

\section{Muscle disease}

http://ng.neurology.org//cgi/collection/muscle_disease

Information about reproducing this article in parts (figures,tables) or in its entirety can be found online at:

http://ng.neurology.org/misc/about.xhtml\#permissions

Information about ordering reprints can be found online: http://ng.neurology.org/misc/addir.xhtml\#reprintsus

Neurol Genet is an official journal of the American Academy of Neurology. Published since April 2015, it is an open-access, online-only, continuous publication journal. Copyright Copyright @ 2019 The Author(s). Published by Wolters Kluwer Health, Inc. on behalf of the American Academy of Neurology.. All rights reserved. Online ISSN: 2376-7839.

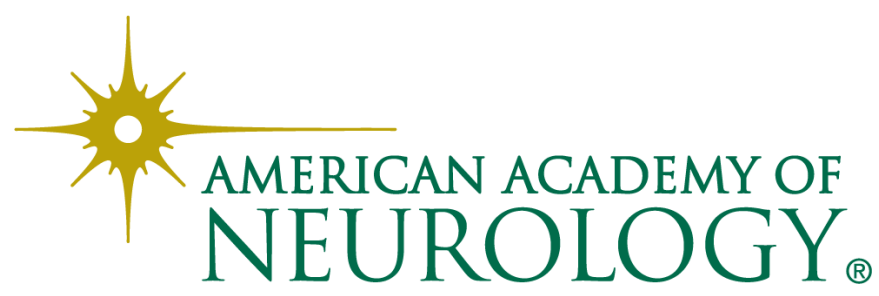

